\title{
Relationship between some Firm-specific Factors and Accrual Based Earnings Management: An Empirical Assessment on Indian Food Processing Industry
}

\author{
Amardeep Pramanik* and Som Sankar Sen**
}

\begin{abstract}
Due to consequent accounting scandals in the financial markets, Earnings Management has become an important topic of research. Based on prior literature in the area of Earnings Management, this study aims to offer an investigation to find the relationship between some firm-specific factors and Earnings Management in respect of Indian Food Processing Industry. Specifically, it seeks to review the relationship between Free Cash Flows, Operating Cycle, Profitability, Earnings Management Flexibility, Asset Tangibility, and Firm Size on Accrual Based Earnings Management on panel data framework. Using the Fixed Effect Model the study finds a positive impact of two independent variables, namely, Free Cash Flows and Profitability on the Earnings Management. On the contrary, no relationship has been found between other independent variables and Earnings Management.
\end{abstract}

Key Words: Accrual Based Earnings Management, Free Cash Flow, Operating Cycle, Profitability.

\section{INTRODUCTION}

In today's world, earnings management is one of the most attractive and widespread topics for researchers, investors, and financial analysts, among others. Schipper (1989) defined earnings management as a "purposeful intervention in the external financial reporting process with the intent of obtaining some private gain." There are three potential techniques through which earnings management can be carried out.

The first technique is Accrual Based Earnings Management, where managers adjust accounting estimates and accounting policies to manipulate reported earnings. To be more specific, managers recognize revenue before they have been earned or by delaying the recognition of expenses which have already been incurred.

The second technique is identified as Real Activities Based Earnings Management. Here, managers of the firm intentionally make operating decisions that have an effect on cash flow to alter reported profit.

The third technique of earnings management is termed as Classification Based Earnings Management. This type

M.Phil. Research Scholar, Department of Commerce, The University of Burdwan, Old Humanities Building, Burdwan, West Bengal-713104 E-mail: skylink.adp@gmail.com (Corresponding Author)

** Department of Commerce, The University of Burdwan, Old Humanities Building, Burdwan, West Bengal -713104

E-mail: somsankarsen@gmail.com 
of earnings management occurs when core expenses are transferred to extraordinary items in the Statement of Profit and Loss to increase earnings before extraordinary items.

This paper attempts to examine the relationship between some firm-specific components and Accrual based Earnings Management practices in respect of Indian Food Processing Industry. More specifically, this paper aims to investigate priory relationships between Free Cash Flow, Operating cycle, Profitability, Earnings Management Flexibility, Asset Tangibility, Firm Size, and Accrual based Earnings Management practices taking samples out of Indian Food Processing Industry.

This paper is epitomized as follows: Section 2 outlines the review of literature section 3 narrates the objective, database and methods, section 4 reports the results and findings, and section 5 presents the conclusion.

\section{REVIEW OF LITERATURE}

In this section, relevant prior studies have been discussed to find the research gap and formulating hypotheses.

\section{Free Cash Flow and Accrual based Earnings Management:-}

Chung et al (2005) attempted to examine the impact of free cash flow on earning management of US firms. The study found managers of the low-growth firms were risk-averse and had an interest in projects with a negative net present value. Therefore, managers of low-growth firms with high free cash flow might use their discretionary power to increase reported earnings to compensate for low or negative earnings. The study conducted by Bukit and Iskandar(2009) on Malaysian firms to examine whether free cash flow is associated with accrual-based earnings management found a significant positive relationship between earnings management and free cash flow. They report that, in the case of high free cash flow firms, managers were likely to increase their reported earnings. They spent on those projects which were not at all wealth maximizing project for the shareholders. Consistent with this argument, Bhundia (2012) investigated the same relationship and found that there was a significant positive relationship between earnings management and free cash flow on the firms listed in Indian stock exchange. Another attempt made by Chalak and Mohammdnezhad (2012) to examine the linkage between free cash flow and accrual-based earnings management of companies listed on Tehran securities exchange and reported a significant positive relationship between free cash flow and earnings management in case of low growth firm having high free cash flow. Consistent with this, Cardoso et al. (2014) conducted a study to investigate whether there was any relationship between free cash flows and earnings management on Brazilian firms from 2008 to 2012. Discretionary accruals estimated by the 'modified Jones model (1991)' and multiple regression were employed to estimate the relationship. They found the same result that the firms of low growth perspective and excess free cash flows were more likely to manage earnings to increase profits. Kangarluei et al. (2014) investigated and compared free cash lows in firms listed in Tehran stock exchange with an emphasis on earnings management. The sample size consists of firms listed in the Tehran stock exchange during 2004-2010. The finding showed the positive relationship between free cash flow and earnings management. Findings from the Levin test indicated that the relationship was more significant for high free cash flow firms than one with low free cash flow firms. Another investigation made by Farhani et al. (2016) on enterprise listed in Tehran stock exchange from 2009 to 2014. The study reported that there was a significant relationship between free cash flow and earnings management in an enterprise with low growth, but no relationship was found between free cash flow and earnings management in an enterprise with high growth. Hastuti et al (2018) conducted a study to test the influence of free cash flow on earnings management at six manufacturing firms listed in Indonesian stock exchanges from 2012 to 2016 . They 
found that free cash flow influences earnings management positively. Results indicated that high free cash flow firms tend to practice earnings management by investing in a non-profitable project rather than distributing it to the shareholder. The manager put much effort to maximize his utility and ignored the welfare of the stakeholders. Alzoubi (2016)found that there is a significant positive relationship between earnings management and free cash flows in the case of Jordanian firms.

Since most of the firms under the Indian Food Processing Industry have been specified by high free cash flow, the managers tend to manipulate reported earnings to achieve their pre-determined targets. Based on the above review of literature the following hypothesis can be stated:-

\section{H1: There is a significant positive relationship between Free Cash Flows and Accrual based Earnings Management.}

\section{Operating Cycle and accrual-based Earnings Management}

Zang (2012) conducted a study using a large sample of firms over 1987-2008 to establish an association between both the Accrual Based Earnings Management and Real based Earnings Management practice with operating cycle. The findings of the study reveal that firms having a shorter operating cycle might prefer real earnings management because firms having shorter operating cycles may have less accounting flexibility to manipulate accruals and the cost of such manipulation was very high. On the other hand, the firm that had a longer operating cycle might be shifted to Accrual-based Earnings Management could able to meet higher accounting flexibility. Thus, earning management behaviour was affected by the length of the operating cycle.

Supporting her arguments, Beuselinck et al.(2019) made an effort to examine the effect of operating cycle on accrual-based earnings management for a sample of 89 countries and suggested that the firms having longer operating cycle might opt for higher discretionary accruals and firms having shorter operating cycle might prefer real earnings management activities to manipulate reported earnings.

Since most of the firms under the Indian Food Processing Industry have been characterized by a longer operating cycle, it is expected that the managers of these firms may prefer Accrual based earnings management practices. Therefore, the following hypothesis can be drawn:-

\section{H2: There is a significant positive relationship between Operating Cycle and Accrual based Earnings Management.}

\section{Profitability and Accrual-based Earnings Management}

Profitability means the ability of a business to earn a profit. One of the commonly used measurements of profitability is Return on assets. There is a mouthful of studies on Earnings Management literature to accomplish the relationship between Profitability and Accrual-based Earnings Management and a mixed result has been found out from the empirical evidence.

One school of thought believes that there exists an inverse relationship between Profitability and Accrual-based Earnings Management. In order to maintain a consistent return, meet the expectation of financial analysts and potential investors, less profitable firms may tend to use discretionary accruals to manipulate reported earnings. 
(Sun and Rath, 2009; Im et.al. 2015; Abbadiet.al. 2016; Alzoubi, 2016).

On the other hand, another school of thought argues that Profitability and Earnings Management are positively associated with each other. Since higher profitability indicates better financial performance leading to a higher incentive for the managers.(Koh, 2003; HessayriandSaihi, 2015; Ghazali, et.al, 2015).

Since most of the firms under the Indian Food Processing Industry have been characterized by higher profitability, it is expected that the managers of these firms may prefer Accrual based earnings management practices. Therefore, the following hypothesis can be drawn:-

H3: There is a significant positive relationship between Profitability and Accrual based Earnings Management.

\section{Earnings Management Flexibility and Accrual-based Earnings Management}

Earnings Management Flexibility is measured by a ratio of Inventories and Trade receivables as a percentage of Total Assets. Since holding the more current asset in the form of inventories and trade receivables may help the manager to influence reportable earnings through discretionary accruals, so it is expected that higher Earnings Management Flexibility may lead to higher Accrual-based Earnings Management practices. Therefore, the following hypothesis can be stated:-

H4: There is a significant positive relationship between Earnings Management Flexibility and Accrual based Earnings Management.

\section{Asset Tangibility and Accrual-based Earnings Management}

Asset Tangibility can be defined as a ratio of property, plant, and equipment to the total asset. Asset Tangibility also related to Earnings Management practice because the level of the firm's current and non-current assets can influence the manager to manipulate reported earnings as per their requirements (Sun and Rath, 2009). The firm having higher Asset Tangibility ratio, more difficult for the manager to manipulate reported earnings since holding more non-current assets does not provide more space for flexibility in accounting practice. But if a firm holds more current asset then the manager can use their discretionary power to influence reported earnings through accruals.

Since most of the firms under Indian Food Processing Industry has been characterized by high Asset Tangibility ratio, Therefore, the following hypothesis can be established:-

H5: There is a significant negative relationship between Asset Tangibility and Accrual based Earnings Management.

\section{Firm size and Accrual-based Earnings Management}

One school of thought believe that there exists an inverse relationship between Firm size and Accrual-based Earnings Management. Larger the firm may have a more strong internal control system which eliminates the 
chances of Earnings Management. Apart from that, experienced and better Auditor's scrutiny, greater scrutiny from Analyst, investors, high reputation cost leads to mitigate Earnings Management practice (Kim et.al.,2003; Lemma et.al.,2013; Sun and Rath,2009; Kuo et.al.,2014; Omid et.al.,2012; Abbadi et.al.,2016; Heninger,2001; Siregar and Utama,2008).

On the other hand, another school of thought argues that Firm Size and Earnings Management are positively associated with each other. In order to disclose more consistent earnings, greater incentives to smooth earnings, higher bargaining power with the auditor, the pressure to meet or beat expectation, a larger representation of the current asset in the total asset may lead to more Earnings management practice (Lemma et.al.,2013; Nelson et.al.,2002; Michelson et.al.,1995; Moses,1987; Moradi et.al.,2012). Since most of the firms under Indian Food Processing Industry has been designated by a strong internal control system and high reputation cost, these firms are always under the scrutiny of experienced Auditor as well as financial analysts and potential investors. Therefore, the following hypothesis can be established:-

H6: There is a significant negative relationship between Firm Size and Accrual based Earnings Management.

\section{OBJECTIVE, DATABASE AND RESEARCH METHODOLOGY}

\section{Objective}

The sole objective of the study is-

To examine the relationship between firm-specific components namely, Free Cash Flows, Operating Cycle, Profitability, Earnings Management Flexibility, Asset Tangibility, Firm Size and Accrual Based Earnings Management.

\section{Database}

This study is based on secondary data taken from Capitaline Database. The data ranges from 2008-2009 to $2017-$ 2018. This study period is chosen because it covers a fairly long period representing the post-sub-prime crisis.

\section{Sample selection}

This study applies purposive sampling techniques. The sample size consists of 38 companies listed in Indian stock exchanges under the Indian Food Processing Industry from 2008-2009 to 2017-2018. Out of 48 companies being listed in the stock exchange, 10 companies are eliminated since data is not sufficient to meet the requirement. Indian food processing industry is considered because it accounts for 32 per cent of the country's total food market which is one of the largest industries in India and is ranked fifth in terms of production, consumption, export and expected growth (https://www.ibef.org).

\section{Research Variables}

Accrual based earnings management can be estimated through discretionary accruals by using the Modified Jones Model(1995). 


\section{The Jones Model}

Accrual based Earnings Management is estimated by discretionary accruals, which is computed by subtracting Nondiscretionary accruals from Total accruals.

\section{Step-1}

There are two methods to calculate Total accruals.

1. Balance Sheet Approach.

2. Cash Flow statement Approach.

\section{Under Balance Sheet Approach}

$\mathrm{TA}_{\mathrm{t}}=\Delta \mathrm{CA}_{\mathrm{t}}-\Delta \mathrm{Cash}_{\mathrm{t}}-\Delta \mathrm{CL}_{\mathrm{t}}+\Delta \mathrm{DCL}_{\mathrm{t}}-\mathrm{DEP}_{\mathrm{t}}$

Where

$\mathrm{TA}_{\mathrm{t}}=$ Total Accruals in the year $\mathrm{t}$.

$\Delta \mathrm{CA}_{\mathrm{t}}=$ the change in current asset in the year $\mathrm{t}$.

$\Delta \mathrm{Cash}_{\mathrm{t}}=$ the change in cash and cash equivalent in the year $\mathrm{t}$.

$\Delta \mathrm{CL}_{\mathrm{t}}=$ the change in current liability in the year $\mathrm{t}$.

$\Delta \mathrm{DCL}_{\mathrm{t}}=$ the change in debt included in current liability in the year $\mathrm{t}$.

$\mathrm{DEP}_{\mathrm{t}}=$ depreciation and amortization expenses in year $\mathrm{t}$.

\section{Under Cash flow statement Approach}

$\mathrm{TA}_{\mathrm{t}}=$ Earnings before extraordinary items - operating cash flows

\section{Step - 2}

The following model is used to obtain estimates of the firm-specific parameters :-

$T A_{t} A_{t-1}=\alpha_{1}\left(\frac{1}{A_{t \mid 1}}\right)+\alpha_{2}\left(\frac{\Delta R E V}{\mathrm{~A}_{t-1}}\right)+\alpha_{3}\left(\frac{P P E_{t}}{\mathrm{~A}_{t \mid 1}}\right)+\varepsilon_{\mathrm{t}}$

$\mathrm{TA}_{\mathrm{t}}=$ Total accruals in the year $\mathrm{t}$.

$\varepsilon_{\mathrm{t}}$ is the residuals, which represents firm-specific discretionary portion of total accruals. 
$\Delta R E V_{\mathrm{t}}=$ Revenue in the year t less revenue in the year $\mathrm{t}-1$.

$P P E=$ Gross property, plant and equipment at the end of the year $\mathrm{t}$.

$A_{t-l}=$ Total assets at the end of year $\mathrm{t}-1$.

$\alpha_{1}, \alpha_{2}, \alpha_{3}$ are firm-specific parameters.

Non discretionary accruals can be determined by using the following model

$N D A_{t}=\alpha_{1}\left(\frac{1}{\mathrm{~A}_{\mathrm{t}}}\right)+\alpha_{2}\left(\frac{\Delta R E V_{\mathrm{V}}}{\mathrm{A}_{\mathrm{t}}}\right)+\alpha_{3}\left(\frac{P P E_{\mathrm{E}}}{\mathrm{A}_{\mathrm{t} 1}}\right) \ldots$

$N D A_{t}=$ Nondiscretionary accruals in year $\mathrm{t}$ scaled by lagged total assets.

$\Delta R E V_{\mathrm{t}}=$ Revenue in the year $\mathrm{t}$ less revenue in the year $\mathrm{t}-1$;

$P P E_{\mathrm{t}}=$ Gross property, plant and equipment at the end of the year $\mathrm{t}$.

$A_{t-1}=$ Total assets at the end of year $\mathrm{t}-1$.

$\alpha_{1}, \alpha_{2}, \alpha_{3}$ are firm-specific parameters.

Discretionary accruals can be ascertained by subtracting nondiscretionary accruals from total accruals.

$\mathrm{DA}_{\mathrm{t}}=\mathrm{TA}_{\mathrm{t}}-\mathrm{NDA}_{\mathrm{t}}$

\section{The Modified Jones Model}

One of the important assumptions under Jones Model (1991) is, revenues are nondiscretionary. But, if the discretion is exercised over revenue recognition, then an error may occur while ascertaining discretionary accruals. In order to eliminate such error, Dechow et al (1995) have proposed Modified Jones Model. The purpose of this model is to derive the nondiscretionary portion of total accruals which is subtracted from total accruals to derive discretionary accruals.

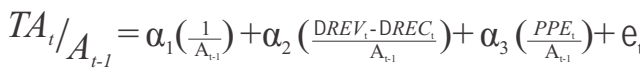

The difference between the stated models is that changes in revenues are adjusted for the changes in receivables in the event period.

Discretionary accruals can be determined by subtracting nondiscretionary accruals from total accruals.

$\mathrm{DA}_{\mathrm{t}}=\mathrm{TA}_{\mathrm{t}}-\mathrm{NDA}_{\mathrm{t}}$ 
The Independent variables can be defined as follows:-

\begin{tabular}{|c|c|c|c|}
\hline$\frac{\text { Independent }}{\text { variables }}$ & Description & $\underline{\text { Measurement }}$ & $\begin{array}{c}\text { The } \\
\text { expected } \\
\text { effect on } \\
\frac{\text { Accrual }}{\underline{\text { EM }}}\end{array}$ \\
\hline 1. Free Cash Flows & $\begin{array}{l}\text { Cash left over after a } \\
\text { company pays for its } \\
\text { operating expenses and } \\
\text { capital expenditure. }\end{array}$ & $\begin{array}{l}\text { Change in net } \\
\text { working capital. }\end{array}$ & Positive \\
\hline 2.Operating Cycle & $\begin{array}{l}\text { Length of time to sell } \\
\text { inventory and collect } \\
\text { cash. }\end{array}$ & $\begin{array}{l}\text { Firm Inventory } \\
\text { Period + Account } \\
\text { receivable period }\end{array}$ & Positive \\
\hline 3.Profitability & Return on Asset. & PAT / Total Asset & Positive \\
\hline $\begin{array}{l}\text { 4.Earnings } \\
\text { Management } \\
\text { Flexibility }\end{array}$ & $\begin{array}{l}\text { Inventories and Trade } \\
\text { receivables as a } \\
\text { percentage of Total } \\
\text { Asset. }\end{array}$ & $\begin{array}{l}\text { (Inventories + Trade } \\
\text { Receivables )/ } \\
\text { Total Asset }\end{array}$ & Positive \\
\hline 5. Asset Tangibility & $\begin{array}{l}\text { Tangible Asset as a } \\
\text { percentage of Total } \\
\text { Asset. }\end{array}$ & $\begin{array}{l}\text { Tangible Asset / } \\
\text { Total Asset }\end{array}$ & Negative \\
\hline 6.LogFirmSize & The size of the firm. & $\begin{array}{l}\text { Revenue from } \\
\text { operation (converted } \\
\text { into natural log) }\end{array}$ & Negative \\
\hline
\end{tabular}

\section{Research Method}

The present study consists of 38 companies and 10 years. For the empirical analysis, there are three options:

I). Pooled OLS method: $\left(38^{*} 10\right)$ or 380 observations can be pooled and estimate a "grand" regression applying the following model. $S_{\mathrm{it}}=\beta_{1}+\beta_{2} X_{1 \mathrm{it}}+\beta_{3} X_{2 \mathrm{it}}+\beta_{4} X_{3 \mathrm{it}}+\ldots . \mu_{\mathrm{it}}$

Where, $\mathrm{i}($ company $)=1,2,3,4 \ldots \ldots 38$ and $\mathrm{t}($ time $)=1,2,3,4 \ldots \ldots 10$. Here $\mathrm{S}=$ Discretionary Accruals computed 
from the Accrual based Earnings Management (AEM), $X_{1}=$ Free Cash Flow per share $(F C F), X_{2}=$ The operating cycle $(\mathrm{OC}), \mathrm{X}_{3}=$ Return on Assets $(\mathrm{ROA}), \mathrm{X}_{4}=$ Earnings Management Flexibility $(\mathrm{EMF}), \mathrm{X}_{5}=$ Asset Tangibility (AT), $\mathrm{X}_{6}=\log$ Firm Size (lfs).

In this particular model, it is assumed those regressors are non-stochastic, even though they are stochastic they are uncorrelated with the error term.

ii) The fixed effects least squares dummy variable (LSDV) model: In this model, 380 observations will be pooled as above, but the model allows each cross-section unit (in this particular case companies) to have its own (intercept) dummy variable.

The model can be written as $S_{i t}=\beta_{1 i}+\beta_{2} X_{1 i t}+\beta_{3} X_{2 i t}+\beta_{4} X_{3 i t}+\beta_{5} X_{4 i t}+\beta_{6} X_{5 i t}+\beta_{7} X_{6 i t}+\ldots . \mu_{i t}$ (9). The subscript i and $\beta_{1}$ suggest that the intercepts of the 38 companies may be different, but each company's intercept does not vary over time.

iii). The random-effects model (REM): In this model, it is assumed that the intercept values are a random drawing from a bigger population of companies. In this case, 38 companies are drawn from a Universe of such companies and thus here a common mean value for the intercept $\left(\beta_{1}\right)$. The individual difference in the intercept value of each company is reflected in the error term $\left(\varepsilon_{i}\right)$.

Hence, the model can be represented as $S_{i t}=\beta_{1}+\beta_{2} X_{1 i t}+\beta_{3} X_{2 i t}+\beta_{4} X_{3 i t}+\ldots .+\mu_{i t}+\varepsilon_{i}$.

$$
=\beta_{1}+\beta_{2} X_{1 \mathrm{it}}+\beta_{3} X_{2 \mathrm{it}}+\beta_{4} X_{3 \mathrm{it}}+\ldots .+\mathrm{w}_{\mathrm{it}}
$$

Where, $\mathrm{w}_{\mathrm{it}}=\mu_{\mathrm{it}}+\varepsilon_{\mathrm{i}}$. Here $\varepsilon_{\mathrm{i}}$ is the individual specific or cross-sectional specific error component and $\mu_{\mathrm{it}}$ is the combined time series and cross-sectional error component.

To select the appropriate model from the above, the following steps have been considered.

Step 1: Selection between Model 1 and Model 3:Breusch Pagan Test

From Model (iii) we get Variance $\left(\mathrm{w}_{\mathrm{it}}\right)=\sigma_{\varepsilon}^{2}+\sigma_{\mu}^{2}$

If $\sigma_{\varepsilon}^{2}=0$ then there is no difference between model 1 and Model 3 and pooled OLS regression should be applied as per equation 1 since in this situation there are neither subject-specific effects nor they have all been accounted for in the explanatory variables.

To test for the presence of random effects Breusch Pagan Test is used. If the Null Hypothesis

$\mathrm{H}_{0}: \sigma_{\mu}^{2}=0$ then there are no random effects.

$L M=\frac{N T}{2(T-1)}\left(\frac{\left.\sum_{i=1}^{N} \sum_{t-2}^{T} e_{t+1}\right)^{\prime}}{\sum_{i=1}^{N} \sum_{t=1}^{T} \hat{e}_{i t}^{t}}-1\right)$

Then the LM statistics have a Chi-square distribution with one difference. If the computed value of LM is 
significant then $\mathrm{H}_{0}$ will be rejected and there will be random effects.

Step 2: Selection of fixed effects or random effects: Hausman Test

The idea behind the Hausman Test is that both the random effects and fixed effects estimators are consistent if there is no correlation between $\mu_{\mathrm{i}}$ and the explanatory variables. If both estimators are consistent then in large samples the random effects and fixed effects estimates should be similar. On the contrary, if $\mu_{\mathrm{i}}$ is correlated with the explanatory variables the random effects estimator will be consistent.

The Hausman statistics are distributed as $X^{2}$ and is computed as:

$\mathrm{H}=(\mathrm{b}-\mathrm{B})^{\prime}\left(\mathrm{V} \_\mathrm{b}-\mathrm{V} \_\mathrm{B}\right)^{-l}(\mathrm{~b}-\mathrm{B})$

Where;

$\mathrm{b}=$ is the coefficient vector from the consistent estimator.

$\mathrm{B}=$ is the coefficient vector from the efficient estimator.

$\mathrm{V} \_\mathrm{b}=$ is the covariance matrix of the consistent estimator.

$\mathrm{V} \_\mathrm{B}=$ is the covariance matrix of the efficient estimator.

$\mathrm{H}_{0}$ : Difference in the coefficient not systematic.

To use the Hausman command in Stata the consistent fixed effects estimator is listed first and the efficient random effects are listed second.

If the $\mathrm{H}$ statistics is significant the $H_{0}$ is rejected and the fixed effect model is retained.

\section{Unit Root Test}

At the outset, the existence of unit roots in the data series-is required to be determined. For this study, we have chosen the Im, Pesaran, and Shin (IPS, hereafter) Test, which is based on the well-known Dickey-Fuller procedure. IPS begins by specifying a separate ADF regression for each cross-section with individual effects and no time trend:

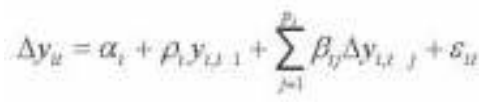

where $i=1, \ldots, N$ and $t=1, \ldots, T$

IPS uses separate unit root tests for the $N$ cross-section units. Their test is based on the Augmented Dickey-fuller (ADF) statistics averaged across groups. After estimating the separate ADF regressions, the average of the $t$ statistics for $\mathrm{p}_{1}$ from the individual $\mathrm{ADF}$ regressions, $\mathrm{t}_{\mathrm{iTi}}\left(\mathrm{p}_{1}\right)$ :

$$
\bar{t}_{N \sigma}=\frac{1}{N} \sum_{i=1}^{N} t_{s}\left(p, \beta_{i}\right)
$$


The $t$-bar is then standardized and it is shown that the standardized $t$-bar statistic converges to the standard normal distribution as $\mathrm{N}$ and $\mathrm{T} \rightarrow \infty$. IPS showed that the $t$-bar test has better performance when $\mathrm{N}$ and $\mathrm{T}$ are small. If $\mathrm{t}$ is significant then the data concerned is stationary.

\section{RESULTS AND DISCUSSION}

The summary statistics of the research variables are presented in Table 1.

Table 1: Summary Statistics

\begin{tabular}{|l|c|c|c|c|c|c|c|}
\hline PARAMETERS & AEM & FCF & OC & PAT_TA & EMF & AT & Ifs \\
\hline Mean & 0.2518911 & 25.51897 & 186.5921 & 0.0758412 & 0.5055287 & 0.538692 & 5.170852 \\
\hline Standard Deviation & 0.5437849 & 114.981 & 1006.911 & 0.2269836 & 0.367091 & 0.4541076 & 2.131653 \\
\hline Minimum & 0.0002277 & -367.96 & 0 & -1.054334 & 0 & 0 & -0.9942523 \\
\hline Maximum & 5.876118 & 797.39 & 19494 & 2.214286 & 2.594895 & 4.960044 & 9.331874 \\
\hline Count & 380 & 380 & 380 & 380 & 380 & 380 & 380 \\
\hline
\end{tabular}

Source:-Author's tabulation using STATA software

Before going into regression it is necessary to check whether the variables are stationary or not which means the existence of unit roots in the data series must be checked. In this study I'm, Pesaran and Shin (IPS, hereafter), which is based on the well-known Dickey-Fuller procedure is used.

Stata codes used for unit root test are as follows:-

\section{xtunitrootips variable, $\operatorname{lags}(1)$}

Here xtunitroot produces the IPS W-t-bar statistics, which has an asymptotically standard normal distribution as $\mathrm{T} \rightarrow \infty$ followed by $\mathrm{N} \rightarrow \infty$.

The result of this test is shown in Table 2 .

Table 2: Unit Root Test Results

\begin{tabular}{|l|c|c|}
\hline \multicolumn{1}{|c|}{ Variables } & W-t-bar statistics & p-value \\
\hline Accruals based Earnings Management(AEM) & -4.3236 & 0.0000 \\
\hline Free Cash Flow (FCF) & -3.8320 & 0.0001 \\
\hline Operating Cycle (OC) & -29.3532 & 0.0000 \\
\hline Profitability (PAT_TA) & -1.9855 & 0.0235 \\
\hline Earnings Management Flexibility (EMF) & -6.2416 & 0.0000 \\
\hline Asset Tangibility (AT) & -4.0984 & 0.0000 \\
\hline Log Firm Size (lfs) & -2.9461 & 0.0016 \\
\hline
\end{tabular}

Source:-Author's own tabulation using STATA software 
From the above table, it is clear that all the $\mathrm{W}$-t-bar statistics are significant. Hence, all the seven variables are stationary at level, i.e., they are all I(0),

The estimated results of equation 8 are presented in Table 3.

Table 3: POOLED OLS MODEL

\section{Panel 1.}

\begin{tabular}{|l|l|}
\hline Number of observation & 380 \\
\hline $\mathrm{F}(6,373)$ & $9.09^{*}$ \\
\hline $\mathrm{R}^{2}$ & 0.13 \\
\hline Adj. $\mathrm{R}^{2}$ & 0.11 \\
\hline
\end{tabular}

Panel 2.

\begin{tabular}{|l|c|c|c|c|c|c|}
\hline AEM & Coef. & Std. Err. & $\mathbf{t}$ & $\mathbf{P}>|\mathbf{t}|$ & \multicolumn{2}{|c|}{$[\mathbf{9 5 \%}$ Conf. Interval] } \\
\hline FCF & 0.0002875 & 0.0002438 & 1.18 & 0.239 & -0.000192 & 0.0007669 \\
\hline OC & -0.0000284 & 0.0000266 & -1.07 & 0.286 & -0.0000806 & 0.0000239 \\
\hline PAT_TA & 0.5340095 & 0.1226142 & $4.36^{*}$ & 0.000 & 0.2929079 & 0.7751112 \\
\hline EMF & 0.2397703 & 0.0770916 & $3.11^{*}$ & 0.002 & 0.0881817 & 0.3913588 \\
\hline AT & 0.1868701 & 0.0613323 & $3.05^{*}$ & 0.002 & 0.0662698 & 0.3074704 \\
\hline lfs & -0.073499 & 0.0139432 & $-5.27^{*}$ & 0.000 & -0.1009161 & -0.0460819 \\
\hline cons & 0.3675219 & 0.081091 & 4.53 & 0.000 & 0.2080692 & 0.5269747 \\
\hline
\end{tabular}

* significant at $1 \%$ level.

The estimated results of equation 10 is presented in Table 4 .

Table 4: RAMDOM -EFFECT GLS REGRESSIO

\section{Panel 1.N}

\begin{tabular}{|l|l|}
\hline Number of observation & 380 \\
\hline $\begin{array}{l}\text { Number of groups } \\
\text { Observation per group }\end{array}$ & 38 \\
\hline $\begin{array}{l}\mathrm{R}^{2}: \text { within }=0.067 \\
\text { between }=0.174 \\
\text { overall }=0.11\end{array}$ & 10 \\
\hline
\end{tabular}




\section{Panel 2.}

\begin{tabular}{|l|c|c|c|c|c|c|}
\hline \multicolumn{1}{|c|}{ AEM } & Coef. & Std. Err. & $\mathbf{z}$ & $\mathbf{P}>|\mathbf{z}|$ & \multicolumn{2}{|c|}{$[\mathbf{9 5 \%}$ Conf. Interval] } \\
\hline FCF & 0.0003196 & 0.0002315 & 1.38 & 0.167 & -0.0001341 & 0.0007733 \\
\hline OC & -0.000015 & 0.0000243 & -0.62 & 0.537 & -0.0000627 & 0.0000327 \\
\hline PAT_TA & 0.3806364 & 0.1199345 & 3.17 & $0.002^{*}$ & 0.1455691 & 0.6157038 \\
\hline EMF & 0.0371521 & 0.1036509 & 0.36 & 0.72 & -0.166 & 0.2403041 \\
\hline AT & 0.2472216 & 0.074765 & 3.31 & $0.001^{*}$ & 0.1006849 & 0.3937584 \\
\hline lfs & -0.0711774 & 0.0200457 & -3.55 & $0.000^{*}$ & -0.1104662 & -0.0318886 \\
\hline cons & 0.4337593 & 0.1180124 & 3.68 & 0.000 & 0.2024592 & 0.6650594 \\
\hline sigma_u & .26137474 & & & & & \\
\hline sigma_e & .43810578 & & & & & \\
\hline rho & .26250088 & & & & & \\
\hline
\end{tabular}

* significant at $1 \%$ level.

In order to select between the Pooled OLS Model and the Random Effect Model Breusch and Pagan Lagrangian multiplier test for random effects test has been applied. The test results have been reported in the Table 5 .

Table 5 :Breusch and Pagan Lagrangian multiplier test for random effects

\section{$\operatorname{AEM}[$ SerialNo,t $]=\mathbf{X b}+\mathbf{u}[$ SerialNo $]+\mathrm{e}[$ SerialNo,t $]$}

\section{Estimated Results}

\begin{tabular}{|c|c|c|}
\hline & Var & sd = sqrt(Var) \\
\hline AEM & 0.295702 & 0.5437849 \\
\hline $\mathbf{e}$ & 0.1919367 & 0.4381058 \\
\hline $\mathbf{u}$ & 0.0683168 & 0.2613747 \\
\hline Test: & $\operatorname{Var}(\mathrm{u})=0$ & \\
\hline $\operatorname{chibar}^{2}(01)=$ & 94.94 & \\
\hline${\text { Prob }>\operatorname{chibar}^{2}=}^{2}$ & 0.0000 & \\
\hline
\end{tabular}

Source:-Author's own tabulation using STATA software

The above table shows that computed value of chibar2 (01) is 94.94 and this value is significant at the $1 \%$ level.

Therefore, it can be concluded that the Pooled OLS Model is not the appropriate model in this study and therefore, 
REM is a better option. The estimated results of equation 9 are presented in Table 6.

Table 6:Fixed-effects (within) regression Model

\section{Panel 1.}

\begin{tabular}{|l|l|}
\hline Number of observation & 380 \\
\hline $\begin{array}{l}\text { Number of groups } \\
\text { Observation per group }\end{array}$ & 38 \\
\hline $\mathrm{R}^{2}:$ within $=0.0767$ & $\mathrm{~F}(6,298) \quad=\quad 4.65^{*}$ \\
between $=0.0737$ & corr(u_i, Xb) $=-0.2599$ \\
overall $=0.0657$ & \\
& \\
\hline
\end{tabular}

Panel 2.

\begin{tabular}{|c|c|c|c|c|c|c|}
\hline AEM & Coef. & Std. Err. & $\mathbf{Z}$ & $\mathbf{P}>|\mathbf{z}|$ & \multicolumn{2}{|c|}{ [95\% Conf. Interval] } \\
\hline FCF & 0.0003013 & 0.000237 & 1.27 & 0.205 & -0.0001649 & 0.0007675 \\
\hline$\overline{\mathrm{OC}}$ & -0.00000834 & 0.0000252 & -0.33 & 0.741 & -0.0000579 & 0.0000412 \\
\hline PAT TA & 0.330166 & 0.1248299 & $2.64 *$ & 0.009 & 0.0846194 & 0.5757125 \\
\hline EMF & -0.1811418 & 0.1345061 & -1.35 & 0.179 & -0.445722 & 0.0834384 \\
\hline AT & 0.3241634 & 0.088857 & $3.65^{*}$ & 0.000 & 0.1493773 & 0.4989495 \\
\hline lfs & -0.0787157 & 0.0304522 & $-2.58 *$ & 0.010 & -0.1386167 & -0.0188146 \\
\hline _cons & 0.5446937 & 0.1590395 & 3.42 & 0.001 & 0.2318551 & 0.8575322 \\
\hline sigma $\mathrm{u}$ & .34139679 & & & & & \\
\hline sigma_e & .43810578 & & & & & \\
\hline rho & .37781567 & & & & & \\
\hline & & 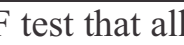 & $-\Omega$. & $6)=$ & & \\
\hline
\end{tabular}

* significant at $1 \%$ level.

Hausman test has been applied to choose between the Fixed Effect Model (FEM) and the Random Effect Model (REM). The test results are presented in Table 7. 
Table 7:Hausman Test

\begin{tabular}{|c|c|c|c|c|}
\hline Coefficients & (b) & (B) & (b-B) & sqrt(diag(V_b-V_B)) \\
\hline & fe & re & Difference & S.E. \\
\hline FCF & 0.0003013 & 0.0003196 & -0.0000183 & 0.0000508 \\
\hline OC & -0.00000834 & -0.000015 & 0.00000668 & 0.00000654 \\
\hline PAT_TA & 0.330166 & 0.3806364 & -0.0504705 & 0.0346152 \\
\hline EMF & -0.1811418 & 0.0371521 & -0.2182939 & 0.0857227 \\
\hline AT & 0.3241634 & 0.2472216 & 0.0769418 & 0.0480183 \\
\hline Ifs & -0.0787157 & -0.0711774 & -0.0075382 & 0.022924 \\
\hline
\end{tabular}

Source:-Author's own tabulation using STATA software

[Where, $\mathrm{b}=$ consistent under Ho and Ha; obtained from xtreg

$\mathrm{B}=$ inconsistent under Ha, efficient under Ho; obtained from xtreg

Test: Ho: difference in coefficients not systematic

$\operatorname{chi} 2(5)=(b-B) '\left[\left(V \_b-V \_B\right)^{\wedge}(-1)\right](b-B)$

$=13.31(\operatorname{Prob}>\operatorname{chi} 2=0.0206)]$

* significant at $5 \%$ level

Table 7 reports that Hausman test statisticisstatistically significant.

Hence, based on the Hausman test it is established that FEM is the appropriate model in this case.

In order to test the Autocorrelation in panel data, Wooldridge test has been applied by using stata code and test result is presented in Table 8:

xtserial AEM FCF OC PAT_TAEMFAT Ifs 
Table 8:- Autocolinearity Test

\begin{tabular}{|c|l|l|l|}
\hline \multicolumn{2}{|l|}{ Wooldridge test for autocorrelation in panel data } & \\
\hline $\mathrm{H}_{0}:$ no first-order autocorrelation & & \\
\hline $\mathrm{F}(1,37)=4.153^{*}$ & & & \\
\hline Prob $>\mathrm{F}=0.0488$ & & & \\
\hline
\end{tabular}

* significant at $5 \%$ level

Source:-Author's own tabulation using STATA software

Table 8 shows that $F$ statistic $(1,37)=4.153$ is highly significant and there is Autocorrelation.

In order to test the heteroskedasticity in panel data, Modified Wald test for group-wise heteroskedasticity in the Fixed Effect regression model has been applied by using the following stata code and the result is presented in Table 9.

.xttest3

Table 9:- HeteroskedasticityTest

\begin{tabular}{|l|}
\hline $\mathrm{H}_{0}: \operatorname{sigma}(\mathrm{i})^{\wedge} 2=\operatorname{sigma}^{\wedge} 2$ for all $\mathrm{i}$ \\
\hline chi2 $(38)=1.1 \mathrm{e}+05$ \\
\hline Prob $>$ chi $2=0.0000$ \\
\hline
\end{tabular}

* significant at $5 \%$ level

Source:-Author's own tabulation using STATA software

Table 9shows thatchi2 $(38)=1.1 \mathrm{e}+05$ is highly significant and there is group-wise heteroskedasticity.

To remove the above problems FEM is re-run after adjusting the standard errors by applying the following code:

.xtreg AEM FCF OC PAT_TA EMFAT lfs, fevce(robust)

The modified results of the model are reported in Table 10 
Table 10. Fixed-effects (within) regression Model (Incorporating Robust Standard Error)

\section{Panel 1.}

\begin{tabular}{|l|l|}
\hline Number of observation & 380 \\
\hline $\begin{array}{l}\text { Number of groups } \\
\text { Observation per group }\end{array}$ & 38 \\
\hline $\begin{array}{c}\mathrm{R}^{2}: \text { within }=0.0767 \\
\text { between }=0.0737 \\
\text { overall }=0.0657\end{array}$ & $\begin{array}{l}\mathrm{F}(6,297) \quad \text { corr }\left(\mathrm{u} \_\mathrm{i}, \mathrm{Xb}\right)=-0.2599 \\
\end{array}$ \\
\end{tabular}

Panel 2.

\begin{tabular}{|c|c|c|c|c|c|c|}
\hline AEM & Coef. & Std. Err. & $\mathbf{z}$ & $\mathbf{P}>|\mathbf{z}|$ & \multicolumn{2}{|c|}{ [95\% Conf. Interval] } \\
\hline FCF & 0.0003013 & 0.0000879 & 3.43 & $0.002 *$ & 0.0001233 & 0.0004793 \\
\hline $\mathrm{OC}$ & $-8.34 \mathrm{E}-06$ & $9.05 \mathrm{E}-06$ & -0.92 & 0.363 & -0.0000267 & 0.00001 \\
\hline PAT_TA & 0.330166 & 0.1857406 & 1.78 & $0.084 * *$ & -0.0461802 & 0.7065121 \\
\hline EMF & -0.1811418 & 0.3487806 & -0.52 & 0.607 & -0.8878384 & 0.5255547 \\
\hline AT & 0.3241634 & 0.219722 & 1.48 & 0.149 & -0.1210356 & 0.7693624 \\
\hline 1fs & -0.0787157 & 0.0562076 & -1.4 & 0.17 & -0.1926031 & 0.0351718 \\
\hline _cons & 0.5446937 & 0.4165002 & 1.31 & 0.199 & -0.2992159 & 1.388603 \\
\hline sigma_u & .34139679 & & & & & \\
\hline sigma_e & .43810578 & & & & & \\
\hline rho & .37781567 & & & & & \\
\hline
\end{tabular}

* significant at $1 \%$ level. ** significant at $10 \%$ level.

Source:-Author's tabulation using STATA software

\section{INTERPRETATION}

It has been observed from the above table that there exist a significant positive relationship between Free Cash Flow and Accrual Based Earnings Management. This indicates that higher Free Cash Flows make it easier for the management in the practice of Accrual based Earnings Management. Hence, Hypothesis -1 is accepted. Moreover, amid Profitability and Accrual based Earnings Management, there is a positive association. This 
indicates that an increase in profitability tends to increase in Accrual based Earnings Management. Therefore, Hypothesis -3 is considered. On the contrary, no relationship has been found between other independent variables namely, Operating Cycle, Earnings Management Flexibility, Asset Tangibility, Log Firm Size (Control variable) and Accrual Based Earnings Management.

\section{CONCLUSION}

In a competitive world, creating long-term value is the priority of all companies. The expectation of the company's shareholders is not only achieving smooth earnings at the end of every accounting year but also, getting a true and fair picture of the company represented by its financial statement. Ultimately, a corporate financial statement should be presented in such a way that the potential investors and creditors can make their investments and financing decisions properly.

The findings of the study show that there exists a significant positive influence of Free Cash Flow and Profitability on Accrual based Earnings Management. However, no evidence of association could be traced out between Operating Cycle, Earnings Management Flexibility, Asset Tangibility, log firm size (Control variable), and Accrual Based Earnings Management.

\section{REFERENCES}

Abbadi, S., Hijazi, Q., \& Rahahleh, A. (2016). Corporate Governance Quality and Earnings Management: Evidence from Jordan. Australasian Accounting Business and Finance Journal, 10(2), 54-75.

Alzoubi, E. (2016). Ownership Structure and Earnings Management: Evidence from Jordan. International Journal of Accounting and Information Management, 24(2), 135-161.

Beuselinck, C., Cascino, S., Deloof, M., \& Vanstraelen, A. (2019). Earnings Management Within Multinational Corporations. The Accounting Review, 94(4), 45-76.

Bukit, R., \& Iskandar, T. (2009). Surplus Free Cash Flow, Earnings Management and Audit Committee. International Journal of Economics and Management, 3(1), 204-223.

Bhundia, A. (2012). A Comparative Study between Free Cash Flows and Earnings Management. Business Intelligence Journal, 5(1), 123-129.

Cardoso, F. T, Martinez, A. L., \& Teixeira, A. J. C. (2014). Free Cash Flow and Earnings Management in Brazil: The Negative Side of Financial Slack. Global Journal Of Management and Business Research.

Chung, R., Firth, M., \& Kim, J. (2005). Earnings Management, Surplus Free Cash Flow, and External Monitoring. Journal of Business Research, 58, 766-776.

Chalak, S., \& Mohammadnezhad, S. (2012). Investigation of the Relationship between Earnings Management and free Cash Flows in Firms with High Free Cash Flows and Low Growth Listed In Tehran Securities Exchange. World Applied Sciences Journal, 20(3), 429-437.

Farahani,Z., Mehri, M. G., \& Pooya, M. R. K. (2016). The Effect of Free Cash Flows on the Evidence of Earnings Management in Enterprises Listed on the Tehran Stock Exchange. International Research Journal of Applied and Basic Sciences, 10(5), 602-609.

Ghazali, A., Shafie, N., \& Sanusi, Z. (2015). Earnings Management: An Analysis of Opportunistic Behaviour,Monitering Mechanism, and Financial Distress",Procedia Economics and Finance, 28, 190-201.

Heninger, W. (2001). The Association between Auditor Litigation and Abnormal Accruals. The Accounting Review,76(1), 111-126. 
Hessayri, M., \& Saihi, M. (2015). Monitoring Earnings Management in Emerging Markets: IFRS Adoption and Ownership Structure. Journal of Economics and Administrative Science, 31(2), 86-108.

Hastuti, C. S. F, Arfan, M., \& Diantimala,Y. (2018). The Influence of Free Cash Flow and Operating Cash Flow on Earnings Management at Manufacturing Firms Listed in the Indonesian Stock Exchange. International Journal of Academic Research in Business and Social Science, 8(9), 1133-1146.

Ho, L., Liao, Q., \& Taylor, M. (2015). Real and Accrual-Based Earnings Management in the Pre- and Post-IFRS Periods: Evidence from China. Journal of International Financial Management and Accounting, 26(3), 294-335.

Im, K.S., Pesaran, M. H., \& Shin, Y. (2003). Testing for unit roots in heterogeneous panels. Journal of Econometrics, 115, 53-74.

Im., C., Kim, J., \& Choi, M. (2015). Dividend Policy and Earnings Management: Based on Discretionary Accruals and Real Earnings Management. Advanced Science and TechnologyLetters, 114, 33-39.

Kangarlouei,S. J., Ramizipour, B., \& Motavassel, M. (2014). Investigation of the Impact of Free Cash Flows on Financial Flexibility and Dividend Policy in Firms Listed in Tehran Stock Exchanges(TSE). International Journal of Banking, Risk and Insurance, 2(2).

Kato, K., Kunimura, M., \& Yoshida, Y. (2002). Dividend Behaviour and Pure Accrual Management of Japanese Banks. Retrieved from www.ssrm.com/sol3/papers.cfm?abstract_id $=365960$

Kim,Y., Liu, C., \& Rhee, S. (2003). The Effect of Firm Size on Earnings Management. (Working paper). University of $\quad \mathrm{H}$ a w a i i. $\quad$ R e tri e ved $\quad$ f r o m https://citeseerx.ist.psu.edu/viewdoc/download?doi=10.1.1.518.3838\&rep=rep1\&type=pdf

Koh, P. (2003). On the Association between Institutional Ownership and Aggressive Corporate Earnings Management in Australia. The British Accounting Review, 35(2), 105-128.

Kuo, J., Ning, L., \& Song, X. (2014). The Real and Accrual-Based Earnings Management Behaviours: Evidence from the Split Share Structure Reform in China. The International Journal Of Accounting, 49, 101-136.

Lemma, T., Negash, M., \& Mlilo, M. (2013). Determinants of Earnings Management. Evidence From around the World. Retrieved from www.ssrn.com/sol3/papers.cfm?abstract_id=2370926.

Omid,A., Khalili, P., \& Mohammadi, J. (2012). Type of Earnings Management and the effects of Firm Size, Deviation in Operating Activities and Sales Growth:Evidence from Iran. European Journal of Economics, Finance and Administrative Sciences, 55, 61-71.

Michaelson, S., James, J., \& Charles,W. (1995). A Market Based Analysis of Income Smoothing. Journal of Business Finance and Accounting, 8(4),1179-1195.

Moradi, M., Salehi, M., \& Najari, M. (2012). A Study of the Effective Variables on Earnings Management: Iranian Evidence. Research Journal of Applied Sciences, Engineering and Technology, 4(17), 3088-3094.

Moses, O. (1987). Income Smoothing and Incentives:Empirical Tests using Accounting Changes. The Accounting Review, 62(2), 358-377.

Nelson, M., Elliot,J., \& Tarpley, R. (2002). Evidence from Auditors about Managers'and Auditors'EarningsManagement Decision. The Accounting Review, 77, 175-202.

Schipper, K. (1989). Commentary on Earnings Management. Accounting Horizons.

Siregar, S., \& Utama, S. (2008). Type of Earnings Management and the effect of Ownership Structure, FirmSize, and Corporate Governance Practices: Evidence from Indonesia. The International Journal of Accounting, 43, $1-27$.

Sun, L., \& Rath, S. (2009). An Empirical Analysis of Earnings Management in Australia. International Journal of Human and Social Sciences, 4(14), 1069-1085.

Zang, A. (2012). Evidence of the Trade-off between Real Activities Manipulation and Accrual-Based Earnings Management. The Accounting Review, 87(2), 675-703. 
